\title{
СПОСОБИ ДИНАМІЗАЦІї ЗОБРАЖЕННЯ СВІТУ РЕЧЕЙ В АНГЛІЙСЬКІЙ ХУДОЖНІЙ ПРОЗІ ХVIII-XX СТОЛІТЬ
}

У статті досліджуються шляхи динамізації зображення штучно створених матеріальних об'єктів у діахронічному аспекті. Встановлено, щуо основними чинниками динамізацї є зображення предметного світу з внутрішньої точки зору, що уможливлює варіювання плану показу; застосування прийому контрасту; уособлення предметів; зображення фізичних властивостей предметів, шио змінюються, зокрема кольору та звуку; поєднання сенсорних образів. Виявлено роль вказаних засобів в англійських художніх творах ХVIII-ХХ століть.

Ключові слова: діахронія, світ речей, динамічний опис, зовнішня / внутрішня точка зору, прийом монтажу, контраст, психологізація опису, сенсорний образ, полісенсорне зображення.

Постановка проблеми. Речі є невід’ємною частиною багатьох важливих сторін людського буття. Як зазначає філософ М. Н. Епштейн, існування людини не тільки "складається з речей", але й в значній мірі "відбивається в них" [1: 305]. Штучно створені матеріальні предмети несуть на собі відбиток життєдіяльності людства, соціально-історичних особливостей епохи, відтворюють національний колорит, що робить їх важливим компонентом матеріальної культури народу.

У процесі історичного розвитку функціональне навантаження речі послідовно збільшувалося - від суто утилітарного до того етапу, коли річ "увійшла в сакральну сферу і стала частиною художньої системи" [2: 252]. Явища матеріальної культури стали предметом мистецтва, зокрема словесного. На думку Л. Гінзбург, зображення в літературних творах об'єктивної реальності в її конкретно-предметних формах $€$ одним із шляхів реалізації споконвічної потреби людини відобразити "емпірію свого існування" [3: 102].

Починаючи з XVIII століття письменники все частіше звертаються до відображення дійсності в життєво достовірних предметно-конкретних формах. Зображення світу речей (далі - СР) стає важливим композиційним елементом художнього твору, необхідною умовою його художньо-естетичної цілісності. Під впливом антропоцентричних законів мистецтва відбувається розширення функціонального спектру описів СР: предметні образи формують фон літературної дії, просторово-часовий континуум тексту, відтворюють місцевий, історичний, національний колорит, а також створюють характерологічний портрет персонажів, відображають їх психологічний стан, набувають символічного переосмислення.

Еволюційні зміни позначаються також на мовній організації зображення СР. Розвиток описової техніки протікає, з одного боку, під впливом зміни стильових напрямів у літературі й мистецтві, визначається існуванням загальних принципів відображення дійсності, а з іншого - способи зображення формуються під впливом творчої індивідуальності автора, особливостей його індивідуального стилю.

Однією 3 основних стилістичних якостей, які визначають характер зображення, $є$ динаміка. Письменники не відразу оволоділи часовою перспективою й мистецтвом динамічного зображення персонажів, природи й світу речей, цей процес, як зауважують науковці, тривав довгий час [4: 80; 5: 174]. Становлення способів створення динамічного опису є безумовно важливою часткою загальної картини еволюції зображення СР у художній літературі, тому потребує грунтовного лінгвістичного аналізу в комплексі із дослідженням структури й семантики описів.

Аналіз останніх досліджень і публікацій. Зображення матеріальних артефактів вже тривалий час знаходиться у центрі уваги літературознавців. Великий внесок у дослідження проблеми зробили зокрема такі відомі вчені, як С. С. Аверінцев, Е. Ауербах, Р. Барт, О.М.Веселовський, В. М. Жирмунський, О. О. Корабльов, Д. С. Ліхачов, С. М. Мелетинський, С. В. Шешунова та інші. У роботах цих науковців досліджується взаємозв'язок предметних образів з іншими образними системами художнього твору, індивідуальним світобаченням письменника та стильовими напрямками в літературі та мистецтві.

У низці літературознавчих досліджень частково розглядається питання про еволюцію мовних засобів зображення СР, зокрема вказується на своєрідність описової техніки різних літературних епох, яка виявляється в характері виділених семантичних ознак предмета, засобах досягнення наочності зображення тощо (див., наприклад, роботи О. І. Білецького, М. К. Гея, Г. М. Поспелова, В. С. Халізєва, О. П. Чудакова, та інших).

У лінгвістиці дослідження мовної організації зображення СР спрямовувалося, передусім, на аналіз текстових функцій, синтактико-граматичних та лексико-стилістичних особливостей опису та проводилося переважно в синхронічному аспекті (див., наприклад, роботи М. П. Брандес, А. І. Домашнєва, 
В. А. Кухаренко, Д. В. Мусатової). Деякі аспекти техніки динамічного зображення розглядалися в контексті аналізу композиційно-мовленнєвої форми "динамічний опис".

Мета статті - розглянути становлення шляхів створення динамічного опису СР в англійській художній прозі XVIII-XX століть. Предметом дослідження $є$ композиційно-структурні та лексико-семантичні засоби динамізаціії зображення.

Відмінною ознакою композиційно-структурної побудови зображення СР у художніх творах XVIII століття є переважання статичних розгорнутих описів зосередженої структури. Проте вже в цей період спостерігаємо окремі випадки розосередження структури опису та виділення в дистанційованих фрагментах різних семантичних ознак зображуваного предмета. Зокрема в романі Даніеля Дефо "Robinson Crusoe", центральною темою якого є зображення дій людини, спрямованих на перетворення дикої природи, автор неодноразово звертається до опису житла Робінзона Крузо, характеризуючи його спочатку як нагромадження речей ("a confused heap of goods" [6: 84]), згодом як впорядковане житло ("everything was put in order" [6: 98]) та зрештою як комфортне місце для проживання ("a perfect settlement ... it rendered everything about me so comfortable" [6: 160]. Зіставлення ознак, що позначають різний стан зображуваного об'єкта, створює динамічну картину середовища.

У творах XVIII століття статичний характер більшості описів визначається домінуванням зовнішньої точки зору епічного оповідача, який зображує реальність, абстрагуючись від неї в часі та просторі. Випадки переходу від зображення 3 точки зору епічного оповідача до зображення з точки зору безпосереднього спостерігача (в термінології Б. А. Успенського - зовнішньої і внутрішньої точок зору) носять епізодичний характер. Розглянемо приклад з роману Джонатана Свіфта "Gulliver's Travels":

1) I turned back, and perceived a vast opague body between me and the sun, moving towards the island: it seemed to be about two miles high ... [7: 150];

2) As it approached nearer ... it appeared to be a firm substance, the bottom flat, smooth, and shining very bright ... [7: 151];

3) ... it advanced nearer, and I could see the sides of it encompassed with several gradations of galleries and stairs, at certain intervals ... [7: 151].

Наближення об'єкта (летючого острова) до спостерігача дає змогу представити його різними планами загальним, що фіксує лише контури об'єкта (1), та збільшеним, що дає змогу детальніше зобразити його структуру $(2,3)$. Застосування техніки монтажу привносить в даний опис елемент динаміки та надає зображенню більш реалістичного характеру, оскільки відображає процес безпосереднього спостереження дійсності.

Схожий приклад динамізації зображення СР знаходимо в романі "The History of Tom Jones, a Foundling" Г. Філдінга. Наближення героя до незнайомої споруди супроводжується укрупненням плану показу. Спочатку об'єкт показано здалеку як джерело світла ("They now discovered a light at some distance, to the great pleasure of Jones ..." [8: 590]), у наступному фрагменті передано звукові враження (" ... they heard ... a strange noise that seemed to proceed from some instrument" [8: 590]), зрештою скорочення дистанції уможливлює ідентифікацію об'єкта ("This Jones perceived to be no other than a barn where a great number of men and women were assembled ..." [8: 591]).

У романі "The Expedition of Humphrey Clinker" Т. Смоллетта, представника пізнього Просвітництва динамізація зображення СР досягається шляхом зіставлення оцінних точок зору героїв. У розосереджених фрагментах опису міст, якими подорожують герої, представлено протилежні судження прихильника давнини Метью Брамбла та його юної племінниці, яка із захватом сприймає все нове:

Bath: "noise, tumult and hurry" [9: 62] - "All is gayety ... the splendor of dress and equipage" [9: 67];

London: "an overgrown monster" [9: 118] - "the wonders of this vast metropolis" [9: 122];

Vauxshall: "a composition of baubles, overcharged with paltry ornaments, ill conceived" [9: 119] - "the pleasures of Vauxhall ... the variety of beauties" [9: 124].

Тенденція до динамізації зображення СР посилюється у творах ХІХ століття, що пов'язано, передусім, 3 динамізацією точки зору безпосереднього спостерігача. Такий прийом Д. С. Ліхачов образно називає описом $з$ позиції "людини, яка прогулюється" [10: 264]. Особливо часто цей прийом застосовується в готичних романах, в яких поширеним є мотив дослідження героєм "страшного середовища". Цей мотив слугує для підтримки атмосфери загрози й таємничості, створення необхідного емоційно-психологічного тону оповіді. Перехід на внутрішню точку зору спостерігача дозволяє представити об'єкт різними планами, наприклад:

"... in another part lay a confused heap of things, which appeared to be old lumber. She went up to it and perceived a broken bedstead, with some decayed remnants of furniture, covered with dust and cobwebs ... she ... saw something falling gently among the lumber. ... It was a small roll of paper tied with a string and covered with dust" [11: 128].

Способом динамізації даного опису виступає техніка прогресивного монтажу - поступове укрупнення плану показу: героїня бачить спочатку купу речей, згодом зламаний каркас ліжка та зрештою маленький згорток паперу. Такий прийом надає зображенню емоційної напруженості, створює інтригу, а також 
залучає самого читача в процес спостереження.

Ще більшого значення у творах XIX століття набуває техніка контрастного зображення, яка базується на поширеній у поетиці романтизму опозиції "світло-темрява". Так, в описах маєтку головного героя роману "Jane Eyer" Едварда Рочестера спочатку акцентується ознака "темний": dark, gloom, gloomy, imperfect light, feels like a vault, as if they belonged to a church. Зображення будинку після повернення господаря будується на багаторазовому повторі контрастної ознаки - "світлий": shining, bright, lit, light, glow, ruddy shine, radiance, radiant, bright, brightness, flashed, glow. Зіставлення протилежних ознак створює динамічну картину середовища та водночас виступає імпліцитним засобом характеристики героя.

Техніка контрастного зображення застосовується також у романі Е. Гаскелл "Mary Barton". В описах житла родини Бартон на початку оповіді виділено ознаку "яскравий": glowing, blue-and-white, gay-coloured, bright-green, yellow glare, ruddy, crimson. У зображенні оселі після трагічних подій в житті героїв домінує ознака "тьмяний, похмурий": dingy and comfortless, dingy, dreary-looking.

Важливою особливістю творів XIX століття стає поява психологізованих описів, забарвлених настроєм та емоціями персонажа. Зокрема Ч. Діккенс вважав, що те, яким людина бачить оточуючий світ, $\epsilon$ проекцією ії внутрішнього психологічного стану [12: 58]. Особливо поширеною техніка психологізації зображення СР стає у творах кінця XIX століття. Так, у романі Т. Гарді "Tess of the d'Urbervilles" предметне оточення зображується через призму сприйняття героя, який знаходиться в стані сильного душевного хвилювання:

That dairy house, so humble, so insignificant, so purely to him a place of constrained sojourn ... what was it now? The aged and lichened brick gables breathed forth "Stay!" The windows smiled, the door coaxed and beckoned, the creeper blushed confederacy [13: 214];

But the complexion even of external things seemed to suffer transmutation as her announcement progressed. The fire in the grate looked impish-demonically funny, as if it did not care in the least about her strait. The fender grinned idly, as if it too did not care. The light from the water-bottle was merely engaged in a chromatic problem. All material objects announced their irresponsibility with terrible iteration [13: 297].

Засобом психологізації наведених описів виступають метафори, які наділяють речі ознаками живих істот - здатністю реагувати, виражати емоції й ставлення, мислити, втілювати наміри: breathed, smiled, coaxed, beckoned,blushed confederacy, looked impish, did not care, grinned idly, was engaged, announced their irresponsibility. Завдяки персоніфікаціям зображення насичується інтенсивним внутрішнім рухом, який підсилює емоційний стан героя.

Розвитку техніки динамічного опису сприяє також розширення палітри засобів створення зорової наочності. Письменники цього періоду широко використовують колористичні епітети, які позначають не тільки основні кольори, а й їх відтінки та поєднання. Зображення мінливих природних властивостей кольору дає змогу відобразити зміни середовища, передати існування предметів у часі: "Through the whole building white had turned yellow, yellow nearly black; and ... it had slowly become a dark gap" [14: 398$]$.

Зображення життя в його багатогранності й динаміці утверджується як головний принцип у літературі XX століття. Поширеним способом динамізації зображення СР, як і в попередній період, є відображення колористичних властивостей речей: "The lights change, glow, fade, gold, rose, violet" [15: 677]; "... the light and shadow, which now made the wall grey, now the bananas bright yellow, now made the Strand grey, now made the omnibuses bright yellow" [16: 152].

Іншим фактором, що викликає динамізацію зображення СР, стає розширення кола сенсорних образів окрім візуальних описи насичуються акустичними, тактильними та олфакторними образами. Так, у романі Дж. Джойса "Ulysses" акустичні образи, передані за допомогою звуконаслідувальної лексики, звукового й лексичного повторів, створюють динамічну картину міста: "The bells of George's church. They tolled the hour: loud dark iron. Heigho! Heigho! Heigho! Heigho!" [15: 89]; "The machines clanked in threefour time. Thump, thump, thump" [15: 151]; "Clock whirred ... Clock clacked ... Clock clacked" [15: 312]; "Far in the grey a bell chimed. ...Cuckoo. Cuckoo. Cuckoo"[15: 499].

Письменниця Вірджинія Вулф описує характерне для урбаністичного пейзажу переплетіння звуків та їх мінливі тональності: "... an incredible pause, a suspense ... before Big Ben strikes. There! Out it boomed. First a warning, musical; then the hour, irrevocable" [16: 4]; "It was precisely twelve ... by Big Ben; whose stroke was wafted over the northern part of London; blent with that of other clocks, mixed in a thin ethereal way with the clouds and wisps of smoke and died up there among the seagulls" [16: 103].

Збільшення питомої ваги динамічних описів відбувається також завдяки поєднанню сенсорних образів, що відповідає кінематографічній техніці "вертикального монтажу" (термін С. Ейзенштейна), наприклад:

1) Lying awake, the floor creaked; the house was suddenly darkened ... [16: 35];

2) It was quite empty except for some old rotting sacks and boxes. It echoed a little. The mud floor was as hard as cement, though cracked here and there ... [17: 143];

3) There was a skull on the desk and a strange solemn smell in the room like the old leather of chairs [18: 56];

4) Through the port-hole the houses sparkled like mica in the haze of heat. The cabin smelt closely of women, of powder, nail-varnish, and night-dresses [19: 206]; 
5)The room in the hotel with hunting pictures. Stuffy it was. Sunlight through the slats of the Venetian blinds [15: 121].

У наведених фрагментах спостерігаємо переплетіння різнопланових сенсорних образів - акустичних $\mathrm{i}$ зорових (1), зорових, акустичних і тактильних (2), зорових та олфакторних (3, 4, 5). Полісенсорне зображення створює "ефект присутності" - ілюзію знаходження всередині зображуваної дійсності.

Слід також відзначити, що на процес динамізації зображення СР впливає розширення кола зображуваних артефактів. В урбаністичних пейзажах фігурують зокрема транспортні засоби, створюються кінестетичні образи об'єктів, наприклад:

Then suddenly, as a train comes out of a tunnel, the aeroplane rushed out of the clouds again, the sound boring into the ears of all people ... and the bar of smoke curved behind and it dropped down, and it soared up and wrote one letter after another - but what word was it writing? [16: 23$]$

Динамізація наведеного опису досягається за рахунок семантики лексичних одиниць - дієслів, що означають рух та дію, а також за рахунок синтаксичної побудови тексту - вживання коротких речень, паралельних синтаксичних конструкцій, прийому полісиндетону.

Висновки. Еволюція лінгвістичних засобів зображення СР в англійській художній прозі XVIII-XX століть відображається в мінливому співвідношенні елементів статики й динаміки. У творах XVIII століття зображення СР будується переважно на виділенні статичних, атемпоральних ознак речі. Динаміка досягається шляхом багаторазової експозиції об'єкта, зміни плану показу, зіставлення протилежних оцінних точок зору. Основними способами динамізації зображення СР у літературі XIX століття виступають прийом монтажу, персоніфікація неживої природи у психологізованих описах, техніка колористичного зображення, використання прийому контрасту. У творах XX століття акцент робиться на зображенні мінливих фізичних властивостей кольору, світла і звуку, поєднанні різнопланових сенсорних образів, зображенні предметів у стані руху.

Перспектива дослідження, на наш погляд, полягає у виявленні подальших еволюційних змін у способах створення динамічного опису СР на матеріалі художніх творів постмодернізму.

\section{СПИСОК ВИКОРИСТАНИХ ДЖЕРЕЛ ТА ЛІТЕРАТУРИ}

1. Эпштейн М. Н. Парадоксы новизны : О литературном развитии XIX-XX веков / М. Н. Эпштейн. - М. : Советский писатель, 1988. - 416 с.

2. Чудаков А. П. Предметный мир литературы (К проблеме категорий исторической поэтики) / А. П. Чудаков // Историческая поэтика. Итоги и перспективы изучения. - М. : Наука, 1986. - С. 251-291.

3. Гинзбург Л. Литература в поисках реальности / Л. Гинзбург // Вопросы литературы. - 1986. - № 2. - С. $98-$ 138.

4. Банникова Н. П. Обзор "века разума" / Н. П. Банникова // Вестник Московского университета. - 1986. Cep. 9. -№ 2. - С. 76-81.

5. Кормилов С. И. Художественный историзм и поэтика литературы нового времени / С. И. Кормилов // Литературный процесс : сб. научн. тр. - М. : Изд-во Московского университета, 1981. - С. 145-174.

6. Defoe D. The Life and Adventures of Robinson Crusoe / D. Defoe. - L. : Penguin Books Ltd., 1985. - 287 p.

7. Swift J. Gulliver's Travels / J. Swift. - L. : J. M. Dent and Sons Ltd, 1991. - 318 p.

8. Fielding H. The History of Tom Jones, a Foundling / H. Fielding. - Harmondsworth : Penguin Classics, 1976. $560 \mathrm{p}$.

9. Smollett T. The Expedition of Humphrey Clinker / T. Smollett. - L. : Penguin Books Ltd, 1976. -427 p.

10. Лихачев Д. С. Поэзия садов. К семантике садово-парковых стилей. Сад как текст / Д. С. Лихачев. - СПб. : Наука, 1991. - 370 c.

11. Radcliffe A. The Romance of the Forest / A. Radcliffe. - М. : Радуга, 1983. - 232 p.

12. Manning S. B. Dickens as a Satirist / S. B. Manning. - L. : Yale Univ. Press, 1977. -93 p.

13. Hardy Th. Tess of the d'Urbervilles. A Pure Woman / Th. Hardy. - L. : Penguin Books Ltd, 1985. - 535 p.

14. Dickens Ch. Dombey and Son. In Two Vols / Ch. Dickens. - M. : Foreign Languages Publishing House, 1955. $1049 \mathrm{p}$.

15. Joyce J. Ulysses / J. Joyce. - L. : Penguin Books Ltd, 1993. - 939 p.

16. Woolf V. Mrs Dalloway / V. Woolf. - L. : Penguin Books Ltd, 1992. - 232 p.

17. Murdoch. L. The Bell / L. Murdoch. - L. : Panther Books, 1978. - 317 p.

18. Joyce J. A Portrait of the Artist as a Young Man / J. Joyce. - L. : Harmondsworth : Penguin Books Ltd, 1976. $253 \mathrm{p}$.

19. Green G. The Heart of the Matter / G. Green. - L. : Penguin Books Ltd, 1983. - 272 p.

\section{REFERENCES (TRANSLATED \& TRANSLITERATED)}

1. Epshtein M. N. Paradoksyi noviznyi : O literaturnom razvitii XIX-XX vekov [About the Literary Development of the 19-20th Centuries] / M. N. Epshteyn. - M. : Sovetskiy pisatel, 1988. $416 \mathrm{~s}$.

2. Chudakov A. P. Predmetnyi mir literatury (K probleme kategoriy istoricheskoy poetiki) [The Subject World of Literature (To the Problem of Categories of Historical Poetics)] / A. P. Chudakov // Istoricheskaia poetika. Itogi i perspektivy izucheniia. - M. : Nauka, 1986. - S. 251-291.

3. Ginzburg L. Literatura v poiskakh real'nosti [Literature in Search of Reality] / L. Ginzburg // Voprosy literatury. 1986. - № 2. - S. 98-138. 
4. Bannikova N. P. Obzor "veka razuma" [Review of the Age of Reason] / N. P. Bannikova // Vestnik Moskovskogo universiteta [Moscow State University Journal]. - 1986. - Ser. 9. - № 2. - S. 76-81.

5. Kormilov S. I. Hudozhestvennyi istorizm i poetika literatury novogo vremeni [Art Historicism and Poetics of Modern Literature] / S. I. Kormilov // Literaturnyi protsess [Literary Process] : [sb. nauchn. tr.]. - M. : Izd-vo Moskovskogo universiteta, 1981. - S. 145-174.

6. Defoe D. The Life and Adventures of Robinson Crusoe / D. Defoe. -L. : Penguin Books Ltd., 1985. - 287 p.

7. Swift J. Gulliver's Travels / J. Swift. - L. : J. M. Dent and Sons Ltd, 1991. - 318 p.

8. Fielding H. The History of Tom Jones, a Foundling / H. Fielding. - Harmondsworth : Penguin Classics, 1976. $560 \mathrm{p}$.

9. Smollett T. The Expedition of Humphrey Clinker / T. Smollett. - L. : Penguin Books Ltd, 1976. -427 p.

10. Lihachev D. S. Poeziia sadov. K semantike sadovo-parkovyih stiley. Sad kak tekst [Poetry of Gardens. To the Semantics of Landscape Styles. Garden as a Text] / D. S. Lihachev. - SPb. : Nauka, 1991. - 370 s.

11. Radcliffe A. The Romance of the Forest / A. Radcliffe. - M. : Raduga, 1983. - 232 p.

12. Manning S. B. Dickens as a Satirist / S. B. Manning. - L. : Yale Univ. Press, 1977. - 93 p.

13. Hardy Th. Tess of the d'Urbervilles. A Pure Woman / Th. Hardy. - L. : Penguin Books Ltd, 1985. -535 p.

14. Dickens Ch. Dombey and Son. In Two Vols / Ch. Dickens. - M. : Foreign Languages Publishing House, 1955. $1049 \mathrm{p}$.

15. Joyce J. Ulysses / J. Joyce. - L. : Penguin Books Ltd, 1993. - 939 p.

16. Woolf V. Mrs Dalloway / V. Woolf. - L. : Penguin Books Ltd, 1992. -232 p.

17. Murdoch. L. The Bell / L. Murdoch. - L. : Panther Books, 1978. - 317 p.

18. Joyce J. A Portrait of the Artist as a Young Man / J. Joyce. - L. : Harmondsworth : Penguin Books Ltd, 1976. $253 \mathrm{p}$.

19. Green G. The Heart of the Matter / G. Green. - L. : Penguin Books Ltd, 1983. - 272 p.

\section{Ковалева Т. П. Способы динамизации изображения вещного мира в английской художественной прозе XVIII-XX веков.}

В статье исследуются способы динамизации изображения искусственно созданных материальных объектов в диахроническом аспекте. Установлено, что основными факторами динамизации являются изображение предметного мира с внутренней точки зрения, что делает возможным варьирование плана показа; использование приема контраста; одушевление предметов; изображение изменяющихся физических свойств предметов, в частности ивета и звука; соединение сенсорных образов. Выявлена роль указанных средств в английских художественных произведениях XVIII-XX веков.

Ключевые слова: диахрония, вещчный мир, динамическое описание, внешняя / внутренняя точка зрения, прием монтажа, контраст, психологизиация описания, сенсорный образ, полисенсорное изображение.

\section{Kovalyova T. P. Means of Dynamization of Man-Made Nature Description in the English Fiction of the 18- 20th Centuries.}

In the process of literary development descriptive techniques undergo changes determined by different factors. Dynamics is an important dimension to take into consideration in order to get an objective picture of evolutional changes of man-made nature description in the English fiction of the $18-20^{\text {th }}$ centuries. It has been stated, that language means of dynamization are influenced to a great extent by the narrative perspective. In the novels of the 18th century most descriptions are presented from the point of view of the epic narrator and are characterised by lack of change and movement. Description from the dynamic point of view of a direct observer, who changes his position and sees objects from different distances and perspectives, is only sporadically found in the novels of this period. This is a technique often employed in the novels of the 19th century to create stylistic effects. Contrast is another device through which writers dynamize the image of material objects. In the novels of the 18th century contrast is based on the opposition between evaluative opinions, in the Romantic period it is often based on the opposition "light-darkness". The authors of the $19^{\text {th }}$ century also tend to personify inanimate objects thus creating dynamic psychologized images of them. Colour is widely used by the writers of the 19-20 th centuries to convey changeable properties to artificial objects. In the fiction of the $20^{\text {th }}$ century descriptions often combine different types of imagery - visual, auditory, olfactory, tactile and kinesthetic. The rapid change of sensory images creates a dynamic picture of reality.

Key words: diachrony, man-made nature, dynamic description, external / internal point of view, montage technique, contrast, psychologized description, sensory image, polysensory imagery. 